\title{
Industry differences in respect of corporate environmental reporting in South Africa: A research note
}

\author{
C J de Villiers \\ Department of Accounting \\ and Finance \\ University of Pretoria
}

\author{
D S Lubbe \\ OTK Research Unit for \\ Business Ethics \\ University of OFS
}

\begin{abstract}
Previous research has revealed industry differences in respect of environmental reporting in South Africa. However, these studies concentrated on particular types of environmental reporting and therefore precluded many other types of environmental reporting in the annual reports surveyed. Past surveys also awarded equal credit to any reference to a particular type of environmental information, whether it comprised a single sentence or several pages.

The annual reports of the top 100 companies, in terms of market capitalisation, were analysed and a sentence count of environmental disclosure was done with the use of the Hackston \& Milne (1996) methodology. The group of energy companies was defined as comprising companies in energy-intensive industries or companies that are producers of energy carriers. The survey revealed that these companies disclosed significantly more environmental information than other companies, in total and in each category

These findings are consistent with the notion of legitimacy, which holds that companies cannot prosper if their aims and methods are not perceived to be in line with that of society. For this reason, companies that have the most obvious environmental impact tend to disclose more environmental information than other companies in an effort to legitimise their aims and methods in the eyes of society.
\end{abstract}

\section{Key words}

Environmental reporting

Environmental disclosure

Environmental accounting 


\section{Introduction and statement of the problem}

In a recent paper, De Villiers \& Barnard (2000) investigated whether there are differences between industries in respect of corporate environmental disclosure or reporting in South Africa. They analysed annual reports in search of specified types of environmental information. Environmental reporting was disregarded if it was not of a specified type.

Hackston \& Milne (1996) used, and comprehensively described, a method for analysing information contained in annual reports that includes all types of social disclosure. Environmental disclosure is one type of social disclosure. In the Hackston \& Milne (1996) method, the number of social disclosures is measured in terms of the number of sentences used.

In this study, the Hackston \& Milne (1996) method of annual report analysis is used to establish whether there are differences between industries in respect of the quantity of corporate environmental disclosure in South Africa.

\section{Theoretical framework}

During the past two or three decades, corporate environmental reporting has increasingly attracted the attention of researchers (for example, Ernst and Ernst 1972-1978; Rockness 1985; Harte and Owen 1991; Gray et al 1995; Mathews 1997). Environmental reporting can be regarded to be a subdivision of the larger area of social reporting. As in most other disciplines, there is considerable disagreement amongst academics on the theoretical underpinning of social and environmental reporting. In the context of this paper, social reporting is considered to be part of the information supplied to stakeholders in the broadest sense of the term.

One of the more popular theories used to explain environmental reporting and other forms of voluntary disclosure is the notion of legitimacy. This notion states that an organisation will be unable to thrive, and indeed even survive, if its aims and methods are not in line with that of society (Shocker \& Sethi 1974). Adams et al (1998); Brown \& Deegan (1998); Deegan \& Gordon (1996); Lindblom (1994) and Patten (1992) are examples of environmental disclosure studies in the accounting literature that used a legitimacy framework.

Lindblom (1994) describes various strategies that corporations can use for environmental reporting in an attempt to legitimise their aims and methods in the eyes of society. Companies that have the most obvious environmental impact have more reason to attempt to legitimise their 
environmental actions and will therefore be more inclined to use environmental disclosure.

The practice of environmental performance reporting appears to be increasing throughout the world (Gray et al 1995; Deegan and Gordon 1996; KPMG 1997). As an additional indication of its apparent importance, many reporting guidelines have been issued and many environmental reporting awards instituted worldwide (for example the ACCA award in the UK, WWF (SA) award in South Africa and Annual Report Awards Inc. in Australia). Examples of reporting guidelines include those of the Public Environmental Reporting Initiative (PERI 1994), Canadian Institute of Chartered Accountants (CICA 1993) and United Nations (1998).

\section{Hypothesis development}

Many studies, both local (De Villiers \& Barnard 2000; De Villiers \& Visser 1998; Doppegieter \& De Villiers 1996) and international (Deegan \& Rankin 1999; Tilt \& Symes 1999; Hackston \& Milne 1996; Gray et al 1995), have revealed that there are differences between industries in respect of environmental reporting.

Doppegieter \& De Villiers (1996:37) found that organisations in the energy sector disclose environmental issues more comprehensively than the top companies in the overall South African economy. Although Doppegieter \& De Villiers (1996) do not mention the notion of legitimacy, their finding is consistent with legitimacy theory. In other words, companies that have the most obvious environmental impact (energy companies) use environmental disclosure more often than other companies in an effort to legitimise their aims and methods.

The following hypothesis can therefore be stated for the study reported in this paper:

Companies in energy-intensive sectors and companies that produce energy carriers disclose a greater volume of environmental information in their annual reports than companies in other industry sectors.

\section{$4 \quad$ Method and sample}

The annual reports of South African companies were analysed by means of the method used by Hackston \& Milne (1996). In this method, any information in an annual report that relates to the environment is counted in terms of the number of sentences used. The information is then classified in the following categories: monetary, non-monetary quantitative or declarative information as well as good news, bad news or neutral news. The perspective of the reporting company was used to 
decide whether a particular statement constituted good, bad or neutral news (compare Hackston \& Milne 1996).

The sample comprised the 1998 annual reports of the top 100 companies, in terms of market capitalisation, listed on the Johannesburg Stock Exchange (JSE) on 30 June 1998. For various reasons, the annual reports of thirteen of the top 100 companies could not be included in the sample. The sample therefore comprised 87 companies. The following reasons applied to the exclusion of the annual report of some companies:

- 7 companies were de-listed after 30 June;

- 3 companies were holding/subsidiary companies that had combined annual reports;

- 1 company was newly listed and did not produce a 1998 report; and

- $\quad$ attempts to obtain the annual report of two of the companies were not successful.

The 100 companies and their industry sectors are listed in appendix A.

The 87 companies included in the sample were split into an energy group and a non-energy group. The category "energy group" was defined as comprising companies that have operations of an energyintensive nature and/or companies that produce energy carriers (such as coal) (compare Doppegieter \& De Villiers 1996:30). Twenty companies were classified in the energy group, which represents the following industry sectors:

- $\quad$ Chemicals, oils and plastics (3 companies);

- $\quad$ metals and minerals (3);

- $\quad$ mining (7);

- $\quad$ mining financial (6); and

- $\quad$ steel and allied (1).

The non-energy group included 67 companies in the following sectors:

- $\quad$ Banks and financial services (11 companies);

- $\quad$ beverages, hotels and leisure (4);

- $\quad$ electronic and electrical (3);

- $\quad$ engineering (1);

- $\quad$ food (4);

- $\quad$ furniture, household and allied (3);

- $\quad$ industrial holding (12);

- $\quad$ insurance (12);

- $\quad$ media (6);

- $\quad$ motor (1); 
- $\quad$ packaging and printing (1);

- $\quad$ pharmaceutical and medical (1);

- $\quad$ stores (6);

- $\quad$ development (1); and

- $\quad$ redevelopment (1).

\section{$5 \quad$ Results and Comments}

The results of the analysis are stated in table 1 . The average number of sentences used per company, total number of sentences used and relevant standard deviations appear in column $A$. Column $B$ reflects the results of a one-tailed ANOVA that compares the group of energy companies with the group of non-energy companies.

Table 1: Environmental reporting in the 1998 annual reports of the top 100 (in terms of market capitalisation) listed companies measured in terms of the average number of sentences used per company

Column A: Average number of sentences used per company (total number of sentences in brackets) [standard deviation in squared brackets]

\begin{tabular}{|c|c|c|c|}
\hline & $\begin{array}{l}\text { Energy group* } \\
20 \text { companies }\end{array}$ & & $\begin{array}{l}\text { Average } \\
87 \text { companies }\end{array}$ \\
\hline $\begin{array}{l}\text { Monetary } \\
\text { - Good news } \\
\text { - Bad news } \\
\text { - Neutral news } \\
\text { Non-monetary } \\
\text { quantitative } \\
\text { - Good news } \\
\text { - Bad news } \\
\text { - Neutral news } \\
\text { Declarative } \\
\text { - Good news } \\
\text { - Bad news } \\
\text { - Neutral news } \\
\text { TOTAL } \\
\text { Good news } \\
\text { Bad news } \\
\text { Neutral news } \\
\text { TOTAL }\end{array}$ & $\begin{array}{l}5.7(113) \\
5.6(112)[4.8] \\
0.0(0) \quad[-] \\
0.1(1) \quad[-] \\
1.8(35) \\
1.5(30)[2.8] \\
0.3(5) \quad[0.5] \\
0.0(0) \quad[-] \\
21.0(420) \\
20.3(405)[24] \\
0.4(7) \quad[1] \\
0.4(8) \quad[1.5] \\
28.4(568)[29] \\
27.4(547) \\
0.6(12) \\
0.5(9) \\
28.4(568)\end{array}$ & $\begin{array}{l}0.1(4) \\
0.1(4)[1.4] \\
0.0(0)[-] \\
0.0(0)[-] \\
0.1(6) \\
0.1(6)[1] \\
0.0(0)[-] \\
0.0(0)[-] \\
1.2(82) \\
1.1(76)[3.7] \\
0.0(0)[-] \\
0.1(6)[1] \\
1.4(92)[3.1] \\
1.3(86) \\
-(0) \\
0.1(6) \\
1.4(92)\end{array}$ & 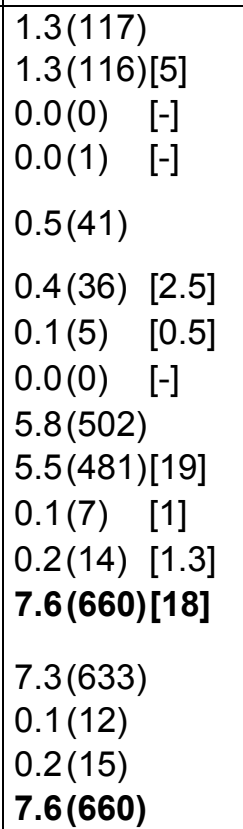 \\
\hline
\end{tabular}

* The group of energy companies was defined as comprising companies that have energy-intensive operations and/or are producers of energy carriers. 
Column B: Comparison of the extent of environmental reporting by companies in energy-intensive industries* versus other companies ANOVA between subjects compared

\begin{tabular}{|l|c|c|c|c|}
\hline & df & Mean Square & F Value & $\begin{array}{c}\text { Probability } \\
\text { (one-tailed) }\end{array}$ \\
\hline $\begin{array}{l}\text { Monetary } \\
\text { - Good news }\end{array}$ & 1 & 472.77 & 64.14 & $<.0001$ \\
- Bad news & 1 & - & - & - \\
- Neutral news & 1 & 0.04 & 3.45 & 0.0335 \\
$\begin{array}{l}\text { Non-monetary } \\
\text { quantitative }\end{array}$ & & & & \\
- Good news & 1 & 30.64 & 20.27 & $<.0001$ \\
- Bad news & 1 & 0.96 & 14.23 & 0.0002 \\
- Neutral news & 1 & - & - & - \\
$\begin{array}{l}\text { Declarative } \\
\text { - Good news }\end{array}$ & 1 & 5628.14 & 42.26 & $<.0001$ \\
- Bad news & 1 & 1.89 & 12.78 & 0.0003 \\
- Neutral news & 1 & 1.48 & 3.68 & 0.0292 \\
TOTAL & $\mathbf{1}$ & $\mathbf{1 2 5 0 . 0 7}$ & $\mathbf{5 7 . 2 2}$ & $<.0001$ \\
\hline
\end{tabular}

* The group of energy companies was defined as including companies that have energy-intensive operations and/or are producers of energy carriers.

The companies in the energy group have a higher average of environmental disclosure in every category, except for the two categories in which neither group disclosed information. Every comparison indicates a statistically significant difference at the $5 \%$ level, except in respect of the two categories in which neither group of companies disclosed information. Comparisons in respect of two categories only, namely neutral monetary news and neutral declarative news were not significant at the $1 \%$ level. Differences in respect of all the other comparisons, including the comparison in respect of the total of disclosure, were statistically significant at the $1 \%$ level.

\section{Conclusions}

A sentence count of environmental reporting in the 1998 annual reports of the top 100 (in terms of market capitalisation) listed companies in South Africa reveals that companies in energy-intensive industries disclose significantly more environmental information than the other top 100 companies in all categories of reporting. The group of energy companies comprises companies in energy-intensive industries or companies that are producers of energy carriers, such as coal. The conclusion to be drawn is that differences in the extent of environmental 
reporting in the 1998 annual reports of companies in South Africa are industry-related. This finding is consistent with the notion of legitimacy. In this case, companies that have an obvious environmental impact use environmental disclosure more often than other companies to legitimise their aims and methods in the eyes of society.

These findings, namely that the particular industry has a marked influence on the tendency of companies to disclose environmental information, considered in conjunction with other local and international findings (see hypothesis development section for references), provides sufficient evidence to generalise the findings to other years and to other countries. 


\section{APPENDIX A}

\section{COMPANIES INCLUDED IN THE SURVEY}

\begin{tabular}{|c|c|c|c|c|c|c|c|c|}
\hline \multirow[b]{2}{*}{ Name } & \multirow[b]{2}{*}{ Industry } & \multirow[b]{2}{*}{ Co } & \multirow{2}{*}{$\stackrel{\Perp}{\text { 山े }}$} & Monetary & monetary & \multicolumn{2}{|c|}{ Declarative } & \multirow{2}{*}{$\stackrel{5}{\circ}$} \\
\hline & & & & G $B \quad N$ & G $B \quad N$ & & $\mathbf{N}$ & \\
\hline$A B I$ & Beverages, Hotels \& Leisure & 1 & 0 & & & 1 & & 1 \\
\hline ABSA & Financial & 2 & 0 & & 1 & 1 & & 2 \\
\hline Adcock & Pharmaceutical \& Medical & 3 & 0 & & & 2 & & 2 \\
\hline African Harvest & Redevelopment & 5 & 0 & & & & & 0 \\
\hline African Life & Insurance & 6 & 0 & & & & & 0 \\
\hline Afrox & Engineering & 7 & 0 & & & & & 0 \\
\hline AMB Holdings & Financial & 8 & 0 & & & & & 0 \\
\hline Barlows & Industrial Holding & 15 & 0 & & & 1 & & 1 \\
\hline Bevcon & Beverages, Hotels \& Leisure & 16 & 0 & & & & & 0 \\
\hline Bidvest & Industrial Holding & 17 & 0 & & & 1 & & 1 \\
\hline BOE & Financial & 19 & 0 & & & & & 0 \\
\hline Cadbury & Food & 20 & 0 & & & 4 & 3 & 7 \\
\hline $\begin{array}{l}\text { Schweppes } \\
\text { Capital Alliance }\end{array}$ & Insurance & & & & & & & \\
\hline CG Smith & Industrial Holding & 22 & 0 & & & 6 & & 0 \\
\hline CG Smith Foods & Food & 23 & 0 & & & 1 & & 1 \\
\hline Coronation & Financial & 24 & 0 & & & & & 0 \\
\hline CTP Holdings & Media & 25 & 0 & & & & & 0 \\
\hline Datatec & Electronics \& Electrical & 26 & 0 & & & & & 0 \\
\hline Didata & Electronics \& Electrical & 28 & 0 & & & & & 0 \\
\hline Edgars & Stores & 30 & 0 & & & 2 & & 2 \\
\hline Educor & Media & 31 & 0 & & & & & 0 \\
\hline Ellerines & $\begin{array}{l}\text { Furniture, Household \& } \\
\text { Allied }\end{array}$ & 32 & 0 & & & 4 & 1 & 5 \\
\hline Fedsure & Insurance & 33 & 0 & & & & & 0 \\
\hline Firstrand & Financial & 34 & 0 & & & & & 0 \\
\hline Forbes & Insurance & 35 & 0 & & & & & 0 \\
\hline Foschini & Stores & 36 & 0 & & & & & 0 \\
\hline Gensec & Financial & 38 & 0 & & & & & 0 \\
\hline $\mathrm{HCl}$ & Insurance & 41 & 0 & & & & & 0 \\
\hline Imperial & Industrial Holding & 42 & 0 & & & & & 0 \\
\hline Investec & Financial & 45 & 0 & & & & & 0 \\
\hline JD Group & $\begin{array}{l}\text { Furniture, Household \& } \\
\text { Allied }\end{array}$ & 47 & 0 & & & & & 0 \\
\hline Johnnic & Industrial Holding & 48 & 0 & & & 1 & & 1 \\
\hline Liberty & Insurance & 49 & 0 & & & & & 0 \\
\hline Liberty Investors & Insurance & 50 & 0 & & & & & 0 \\
\hline Lonrho & Industrial Holding & 51 & 0 & 3 & & 10 & 1 & 14 \\
\hline M-Cell & Development & 52 & 0 & & & & & 0 \\
\hline Mega & Media & 53 & 0 & & & & & 0 \\
\hline Metro & Stores & 54 & 0 & & & & & 0 \\
\hline Metropolitan & Insurance & 55 & 0 & & & & & 0 \\
\hline $\mathrm{MIH}$ & Media & 56 & 0 & & & & & 0 \\
\hline Mutual \& Federal & Insurance & 58 & 0 & & & & & 0 \\
\hline Nampak & Packaging \& Printing & 59 & 0 & & 3 & 3 & & 6 \\
\hline Nedcor & Financial & 60 & 0 & & & & & 0 \\
\hline Omni Media & Media & 61 & 0 & & & & & 0 \\
\hline Pepkor & Stores & 62 & 0 & & & & & 0 \\
\hline PQ Holdings & Electronics \& Electrical & 64 & 0 & & & & & 0 \\
\hline Primedia & Media & 65 & 0 & & & & & 0 \\
\hline Profurn & $\begin{array}{l}\text { Furniture, Household \& } \\
\text { Allied }\end{array}$ & 66 & 0 & & & & & 0 \\
\hline $\begin{array}{l}\text { Real Africa } \\
\text { Holdings }\end{array}$ & Industrial Holding & 67 & 0 & & & & & 0 \\
\hline Rebhold & Beverages, Hotels \& Leisure & 68 & 0 & & & & & 0 \\
\hline $\begin{array}{l}\text { Rembrandt } \\
\text { Holdings }\end{array}$ & Industrial Holding & 69 & 0 & & & 2 & & 2 \\
\hline Remgro & Industrial Holding & 70 & 0 & & 1 & 6 & & 7 \\
\hline Richemont & Industrial Holding & 71 & 0 & & & & & 0 \\
\hline RMB Holdings & Insurance & 72 & 0 & & & & & 0 \\
\hline
\end{tabular}




\begin{tabular}{|c|c|c|c|c|c|c|c|c|c|c|c|}
\hline Name & Industry & Co & யे & $3 \mathrm{~B}$ & $\mathbf{v}$ & G $\mathbf{E}$ & $3 \mathrm{~N}$ & & & $\mathbf{N}$ & $r$ \\
\hline SAB & Beverages, Hotels \& Leisure & 73 & 0 & 1 & & & & 4 & & & 5 \\
\hline Safren & Industrial Holding & 74 & 0 & & & 1 & & 6 & & 1 & 8 \\
\hline Sage & Insurance & 75 & 0 & & & & & & & & 0 \\
\hline Santam & Insurance & 77 & 0 & & & & & & & & 0 \\
\hline Shoprite & Stores & 79 & 0 & & & & & & & & 0 \\
\hline Stanbic & Financial & 80 & 0 & & & & & 1 & & & 1 \\
\hline Supergroup & Motor & 81 & 0 & & & & & & & & 0 \\
\hline Tegkor & Industrial Holding & 82 & 0 & & & & & 2 & & & 2 \\
\hline Theta & Financial & 83 & 0 & & & & & & & & 0 \\
\hline Tiger Oats & Food & 84 & 0 & & & & & 2 & & & 2 \\
\hline Tongaat & Food & 85 & 0 & & & & & 16 & & & 16 \\
\hline Trencor & Financial & 86 & 0 & & & & & & & & 0 \\
\hline Woolies & Stores & 87 & 0 & & & & & & & & 0 \\
\hline $\mathrm{AECl}$ & Chemicals, Oils and Plastics & 4 & 1 & 3 & 1 & 10 & 1 & 16 & 3 & & 34 \\
\hline Amcoal & Mining & 9 & 1 & 6 & & 1 & 2 & 22 & & & 31 \\
\hline Amgold & Mining Financial & 10 & 1 & & & & & & & & 0 \\
\hline Amplats & Metals \& Minerals & 11 & 1 & 17 & & & & 69 & 1 & 4 & 91 \\
\hline Anamint & Mining & 12 & 1 & & & & & & & & 0 \\
\hline $\begin{array}{l}\text { Anglo American } \\
\text { Corp }\end{array}$ & Mining Financial & 13 & 1 & & & & & 3 & & & 3 \\
\hline Anglogold & Mining & 14 & 1 & 12 & & 4 & 1 & 26 & & & 43 \\
\hline Billiton & Mining Financial & 18 & 1 & 1 & & 1 & & 26 & & & 28 \\
\hline De Beers & Mining & 27 & 1 & & & 1 & & 38 & & & 39 \\
\hline Driefontein & Mining & 29 & 1 & 11 & & & & 7 & & & 18 \\
\hline Gencor & Mining Financial & 37 & 1 & & & & & & & & 0 \\
\hline GFSA & Mining Financial & 39 & 1 & 3 & & & & 1 & & & 4 \\
\hline Gold Fields & Mining & 40 & 1 & 12 & & & & 4 & & & 16 \\
\hline Implats & Metals \& Minerals & 43 & 1 & 14 & & & & 12 & & & 26 \\
\hline Ingwe & Mining & 44 & 1 & 11 & & 4 & & 87 & 2 & & 107 \\
\hline ISCOR & Steel \& Allied & 46 & 1 & 10 & & 1 & & 9 & & 1 & 21 \\
\hline Minorco & Mining Financial & 57 & 1 & & & & & & & & 0 \\
\hline Polifin & Chemicals, Oils and Plastics & 63 & 1 & & & 3 & 1 & 12 & & & 16 \\
\hline Samancor & Metals \& Minerals & 76 & 1 & 7 & & 1 & & 30 & 1 & & 39 \\
\hline Sasol & Chemicals, Oils and Plastics & 78 & 1 & 5 & & 4 & & 43 & & & 52 \\
\hline & Reason excluded & & & & & & & & & & \\
\hline $\begin{array}{l}\text { Anglo American } \\
\text { Investment Corp. }\end{array}$ & Delisted & 88 & & & & & & & & & \\
\hline Charter & Delisted & 89 & & & & & & & & & \\
\hline F.I.T. & $\begin{array}{l}\text { Two companies' annual } \\
\text { reports combined }\end{array}$ & 90 & & & & & & & & & \\
\hline $\begin{array}{l}\text { Investec } \\
\text { Holdings }\end{array}$ & Annual report not available & 91 & & & & & & & & & \\
\hline $\mathrm{JCl}$ & Delisted & 92 & & & & & & & & & \\
\hline Libhold & $\begin{array}{l}\text { Three companies' annual } \\
\text { reports combined }\end{array}$ & 93 & & & & & & & & & \\
\hline $\begin{array}{l}\text { Liberty Strategic } \\
\text { Investments }\end{array}$ & $\begin{array}{l}\text { Three companies' annual } \\
\text { reports combined }\end{array}$ & 94 & & & & & & & & & \\
\hline NBS Boland & Delisted & 95 & & & & & & & & & \\
\hline Norwich & Delisted & 96 & & & & & & & & & \\
\hline Orion & Delisted & 97 & & & & & & & & & \\
\hline Orion Holdings & Delisted & 98 & & & & & & & & & \\
\hline Peregrin & $\begin{array}{l}\text { Newly listed, first annual; } \\
\text { report } 1999\end{array}$ & 99 & & & & & & & & & \\
\hline $\begin{array}{l}\text { Real Africa } \\
\text { Investments }\end{array}$ & $\begin{array}{l}\text { Two companies' annual } \\
\text { reports combined }\end{array}$ & 100 & & & & & & & & & \\
\hline
\end{tabular}




\section{Bibliography}

Adams, C.A., Hill, W.Y. \& Roberts, C.B. 1998. Corporate social reporting practices in Western Europe: Legitimating corporate behaviour?, British Accounting Review, Vol. 30, No. 1, pp.1-22.

Brown, N. \& Deegan, C. 1998. The public disclosure of environmental performance information - a dual test of media agenda setting theory and legitimacy theory, Accounting and Business Research, Vol. 29, No. 1, pp.21-41.

CICA 1993. Reporting on environmental performance, The Canadian Institute of Chartered Accountants.

De Villiers, C.J. \& Barnard, P. 2000. Environmental Reporting in South Africa from 1994 to 1999: A research note, Meditari Accountancy Research, Vol. 8, pp.15-23.

De Villiers, C.J. \& Visser, W. 1998. Survey of Environmental Reporting in South Africa - 5th edition, KPMG and Department of Accounting, University of Pretoria, Johannesburg.

Deegan, C. \& Gordon, B. 1996. A study of the environmental disclosure practices of Australian corporations, Accounting and Business Research, Vol. 26, No. 3, pp.187-199.

Deegan, C. \& Rankin, M. 1999. The environmental reporting expectations gap: Australian evidence, British Accounting Review, Vol. 31, No. 3, pp.313-346.

Doppegieter, J.J. \& De Villiers, C.J. 1996. Environmental Reporting Practices in the South African Energy Sector, Management Dynamics, Vol. 5, No. 1, pp.15-42.

Ernst \& Ernst. 1972-1978. Social Responsibility Disclosure Surveys, Cleveland, $\mathrm{OH}$.

Gray, R., Kouhy, R. and Lavers, S. 1995. Corporate social and environmental reporting: A review of the literature and a longitudinal study of UK disclosure, Accounting, Auditing and Accountability Journal, Vol. 8, No. 2, pp.47-77.

Hackston, D. \& Milne, M.J. 1996. Some determinants of social and environmental disclosures in New Zealand companies, Accounting, Auditing and Accountability Journal, Vol. 9, No. 1, pp.77-108. 
Harte, G. \& Owen, D.L. 1991. Environmental disclosure in the annual reports of British companies: A research note, Accounting, Auditing and Accountability Journal, Vol. 4, No. 3, pp.51-61.

KPMG 1997. The KPMG survey of environmental reporting 1997, KPMG, London.

Lindblom, C.K. 1994. The implications of organizational legitimacy for corporate sociel performance and disclosure, Paper presented at the Critical Perspectives on Accounting Conference, New York, N.Y.

Mathews, M.R. 1997. Twenty-five years of social and environmental accounting research: Is there a silver jubilee to celebrate?, Accounting, Auditing and Accountability Journal, Vol. 10, No. 4, pp.481-531.

Patten, D.M. 1992. Intra-industry environmental disclosure in response to the Alaskan oil spill: a note on legitimacy theory, Accounting, Organizations and Society, Vol. 17, No. 5, pp.471-485.

PERI. 1994. PERI Guidelines, Public Environmental Reporting Initiative, Washington D.C.

Rockness, J.W. 1985. An assessment of the relationship between US corporate environmental performance and disclosure, Journal of Business Finance and Accounting, Vol. 12, No. 3, pp.339-355.

Shocker, A.D. \& Sethi, S.P. 1974. An approach to incorporating social preferences in developing corporate action strategies, In Sethi, S.P. (Ed.) The unstable ground: Corporate social policy in a dynamic society, Melville, CA, pp.67-80.

Tilt, C. \& Symes, C. 1999. Environmental disclosure in Australian mining companies: Environmental conscience or commercial reality?, Accounting Forum, Vol. 23, No. 2, pp.137-154.

United Nations. 1998. Position Paper: Accounting and financial reporting for environmental costs and liabilities, United Nations Conference on Trade and Development, Commission on Investment, Technology and Related Financial Matters, Intergovernmental Working group of Experts on International Standards of Accounting and Reporting, Geneva. 